\title{
In vitro Cytotoxicity Studies of Zn (Zinc) Nanoparticles Synthesized from Abutilon indicum $L$. against Human Cervical Cancer (HeLa) Cell Lines
}

\author{
Badarinath Druvarao Kulkarni' ${ }^{1}$, Samim Sultana ${ }^{2}$, Mayuri Bora ${ }^{2}$, Ishita Dutta ${ }^{2}$, Padmaa Milaap Paarakh³ ${ }^{3}$, Vedamurthy Ankala Basappa1 \\ 'Department of Biotechnology and Microbiology, Karnatak University, Dharwad, INDIA. \\ 2Department of Biotechnology, The Oxford College of Science, Bangalore, INDIA. \\ ${ }^{3}$ Department of Pharmacognosy, The Oxford College of Pharmacy, Bangalore-560 068, INDIA.
}

\begin{abstract}
Background: The $\mathrm{Zn}$ nanoparticles synthesized from the plant sources are ecofriendly and are potent anticancer agents. Objective: The objective of the present work was to evaluate In vitro cytotoxic activity of Zn nanoparticles green synthezised from Abutilon indicum extract against HeLa cell lines (cervical cancer). Methods: The aqueous extract is prepared by cold extraction (maceration) using water as a solvent. Phytochemical analysis was done by using the standard procedures. Aqueous extract of $A$. indicum was used for synthesis of $\mathrm{Zn}$ nanoparticles. The nanoparticles were characterized by UV-Visible spectrometry and Scanning electron microscopy (SEM) techniques. In vitro cytotoxicity studies of $\mathrm{Zn}$ nanoparticles were done by MTT assay using HeLa cell lines. Results: The preliminary phytochemical results revealed that the aqueous extract of $A$. indicum contains broad spectrum of secondary metabolites like Tannins, Saponins, Glycosides, Flavonoids, Anthroquinones, Terpenoids and Steroids. The U.V spectrophotometeric analysis of $\mathrm{Zn}$ nanoparticles displayed maximum absorption at $270 \mathrm{~nm}$ and scanning electron microscopic studies showed
\end{abstract}

that the nanoparticles size ranges from $50-500 \mathrm{~nm}$. The MTT assay results revealed that the of $\mathrm{Zn}$ nanoparticles exhibits potent cytotoxicity against HeLa cell lines with $I C_{50}$ value of $45.82 \mu \mathrm{g} / \mathrm{ml}$. Conclusion: Thus the present study concludes that $\mathrm{Zn}$ nanoparticles can be used as a potent drug in alternative therapy for treating the cervical cancer patients.

Key words: Abutilon indicum, Zn nanoparticles, MTT assay, Cervical cancer, Cytotoxicity

\section{Correspondence:}

Dr. Vedamurthy Ankala Basappa, Department of Biotechnology, Karnatak University, Pavate Nagar, Dharwad-580003, Karnataka, INDIA.

Mob no: +919341314101

E-mail: vedamurthybt@gmail.com

DOI: $10.5530 /$ pj.2016.2.5

\section{INTRODUCTION}

Nanoparticles are minute particles with dimension in 1-100 nm large, whose size is comparable to the biological molecules with its new and enhanced size-dependent properties compared to its bulk material, they penetrate more than larger substances and ideally interact with cellular structures. $^{1-3}$ These nanoparticles can be synthesized by chemical processes like pyrolysis, hydrothermal method, chemical precipitation etc. But these chemical processes cause pollution and are costly practices. Synthesis of metal oxide nanoparticles can be done using biological materials such as microbes and plants. Synthesis of nanoparticles using microorganism involves lengthy process of maintaining microbial cultures, intracellular synthesis and multiple purification steps. However using "green" methods in the synthesis of Zinc nanoparticles has increasingly become a topic of interest. Nanoparticles in recent days have revolutionized the modern medicinal practices because of their potential activities in treatment of various diseases. ${ }^{4}$ Plants have been used from centuries to treat various human diseases. Herbal drugs as compared to synthetic drugs have no or lesser side effects and are less expensive. Since plant mediated synthesis is easy and safe with one-step protocol and don't involve the use of harsh solvents or surfactant as the reducing agents, studies have suggested their use to be more ideal and compatible for their use in nanomedicine because of their stability in various biological media. The biomolecules present in plants mediates the synthesis of nanoparticles and also stabilize the nanoparticles formed with desired size and shape as well play a role in reducing the ions to the nanosize, and in the capping of nanoparticles. ${ }^{5}$ Numerous factors such as temperature, $\mathrm{pH}$, concentration of extracts, concentration of raw material, etc. influence the reduction process of metal ions into the metal nanoparticles. ${ }^{6}$ Cancer is a class of disease where abnormal cells proliferate uncontrollably, producing malignant tumors that invade surrounding healthy tissue. Cervical cancers are carcinomas of squamous cell, arising in the squamous (flattened) epithelial cells that line the cervix. Due to serious side effects of currently available cancer treatments-chemotherapy and radiation therapy, death rate is high. Studies have showed that plant derived nanoparticles can be used to treat cancer patients in the near future with minimum side effects. The Plant based $\mathrm{Zn}$ nanoparticles were used because of their inbuilt ability to penetrate tissue and cells and interact with the cancerous cells. ${ }^{7,8}$ This property of $\mathrm{Zn}$-nanoparticles can be further engineered by functionalization with target proteins or chemical groups and rendering them benign to normal cells while retaining their cancer targeting and killing properties. ${ }^{9-11}$ Studies demonstrate that cytotoxic property of $\mathrm{Zn}$ nanoparticles depends on their size i.e-smaller nanoparticles exhibit greater toxicity. ${ }^{12,13}$ The surface charge nature of Zinc nanoparticles is typically due to neutral hydroxyl groups attached to their surface. ${ }^{14,15}$ Also at lower $\mathrm{pH} \mathrm{Zn-nanoparticles} \mathrm{gain} \mathrm{positive} \mathrm{charge} \mathrm{from} \mathrm{the} \mathrm{envi-}$ ronment, which then interact with negatively charged phospholipids on the membrane of cancer cells, thereby promoting cellular uptake, phagocytosis and cytotoxicity. ${ }^{16-18}$ Studies have showed that $\mathrm{Zn}$ nanoparticles exposure at particular concentration induces the production of various pro-imflammatory cytokines that elicitates Th1-mediated immune response which inturnenchances tumor cell killing through production of TNF- $\alpha$ (Tumor Necrosis Factor). ${ }^{19-21} A$. indicum generally known as Country Mallow belongs to the family Malvaceae. It is spread throughout number of tropical and subtropical areas including India. It is a perennial shrub, softly tomentose and grows up to $3 \mathrm{~m}$ in height. It is found as a weed in sub-Himalayan tracts, hills up to $1200 \mathrm{~m}$ and in hotter parts of India. Almost all the parts of $A$. indicum are of medicinal importance 
and used traditionally for the treatment of various ailments such as chest infection, urethritis, strangury, haematuria, leprosy, ulcer, toothache, inflammation of bladder, piles, laxative, in chronic cystitis, gleet and gonorrhea, athritis, seizures and in liver protection. ${ }^{22}$ There are limited numbers of reports available on the cytotoxic effect of $\mathrm{Zn}$ nanoparticles against cervical cancer, so the present study aims at profiling the same.

\section{MATERIALS AND METHODS}

\section{Preparation of leaf extract}

Fresh leaves were collected from Abutilon indicum plants in HSR Layout, Bangalore and it was identified and authenticated by taxonomist. A voucher specimen was deposited in The Oxford College of Pharmacy, Bangalore. The leaves were washed several times with water to remove the dust particles and then shade dried to remove the remaining moisture. The dried leaves were coarsely powdered and then placed in sterile distilled water in a conical flask so that all the crushed leaves were properly dipped in water. The conical flask was placed on a shaker for the cold extraction for 12-15 hrs. The extract was filtered using muslin cloth and the filtrate was poured into petriplate \& dried using dessicator to form a thick jelly like extract. ${ }^{23}$

\section{Preliminary Phytochemical Analysis}

Phytochemical analysis was performed using standard procedures by Harborne JB, 1998. ${ }^{24}$

\section{Synthesis of Zn Nanoparticles}

Zinc acetate dihydrate and sodium hydroxide were used as the precursor material. The dried aqueous extract was dissolved in respective solvent, approximately $3 \mathrm{ml}$ was prepared. Three sets of conical flasks with $50 \mathrm{ml}$ distilled water each were prepared and labeled as $0.25 \mathrm{ml}, 0.5 \mathrm{ml}$ and $1 \mathrm{ml}$ respectively. $0.02 \mathrm{M}$ aqueous Zinc acetate dihydrate $(0.219 \mathrm{gm})$ was added to each of the three flasks under vigorous stirring. After $10 \mathrm{~min}$ stirring aqueous leaf extract of Abutilon indicum were introduced into the above solution with the concentration of $0.25 \mathrm{ml}, 0.5 \mathrm{ml}, 1 \mathrm{ml}$ to the three labeled flasks followed by the addition of aqueous $2.0 \mathrm{M} \mathrm{NaOH}$ resulted in a white aqueous solution at $\mathrm{pH} 12$. The $\mathrm{pH}$ meter was used for adjusting of $\mathrm{pH} . \mathrm{pH}$ of the medium influence the size of $\mathrm{Zn}$ nanoparticles at great concern, which were then positioned in a magnetic stirrer for $2 \mathrm{hr}$. The precipitate were then taken out and washed repetitively with distilled water followed by ethanol to remove the impurities of the final product. Then a white powder of $\mathrm{Zn}$ nanoparticles was obtained after drying at $60^{\circ} \mathrm{C}$ in vacuum oven overnight. ${ }^{25}$

\section{Characterization of Zn Nanoparticles}

The $\mathrm{Zn}$ nanoparticles were characterized by using a UV-Vis spectrometer, the nanoparticle suspension was prepared in deionized water; the sample was analyzed from $200 \mathrm{~nm}$ to $800 \mathrm{~nm}$ range in UV-Vis spectrophotometer. (UV-2450 Agilent) ${ }^{26}$

\section{SEM Observation of Zn Nanoparticles}

The sample was prepared by placing a drop of $\mathrm{Zn}$ nanoparticles on gold coated copper grid for 5-6 min and subsequently drying in air, before transferring it to the microscope operated at an accelerated voltage of 10 KV (JOEL Model 5400).

\section{MTT ASSAY}

\section{Chemicals}

3-(4,5-dimethyl thiazol-2-yl)-5-diphenyltetrazolium bromide (MTT), Fetal Bovine serum (FBS), Phosphate Buffered Saline (PBS),Dulbecco's
Modified Eagle's Medium (DMEM) and Trypsin were obtained from Sigma Aldrich Co, St Louis, USA.EDTA, Glucose and antibiotics from Hi-Media Laboratories Ltd., Mumbai. Dimethyl Sulfoxide (DMSO) and Propanol from E.Merck Ltd., Mumbai, India.

\section{Cell lines and Culture medium}

HeLa (Cervical carcinoma) cell lines were procured from National Centre for Cell Sciences (NCCS), Pune, India. Stock cells were cultured in DMEM supplemented with $10 \%$ inactivated Fetal Bovine Serum (FBS), penicillin $(100 \mathrm{IU} / \mathrm{ml})$, streptomycin $(100 \mu \mathrm{g} / \mathrm{ml})$ and amphotericin B $(5 \mu \mathrm{g} / \mathrm{ml})$ in an humidified atmosphere of $5 \% \mathrm{CO} 2$ at $37^{\circ} \mathrm{C}$ until confluent. The cells were dissociated with TPVG solution ( $0.2 \%$ trypsin, $0.02 \%$ EDTA, $0.05 \%$ glucose in PBS). The stock cultures were grown in $25 \mathrm{~cm}^{2}$ culture flasks and all experiments were carried out in 96 microtitre plates (Tarsons India Pvt. Ltd., Kolkata, India).

\section{Preparation of Test Solutions}

For Cytotoxicity studies, each weighed test drugs were separately dissolved in DMSO and volume was made up with DMEM supplemented with $2 \%$ inactivated FBS to obtain a stock solution of $1 \mathrm{mg} / \mathrm{ml}$ concentration and sterilized by filtration. Serial two fold dilutions were prepared from this for carrying out cytotoxic studies.

\section{Determination of cell viability by MTT Assay}

The monolayer cell culture was trypsinized and the cell count was adjusted to $1.0 \times 10^{5} \mathrm{cells} / \mathrm{ml}$ using DMEM containing $10 \%$ FBS. To each well of the 96 well microtitreplate, $0.1 \mathrm{ml}$ of the diluted cell suspension (approximately 10,000 cells) were added. After $24 \mathrm{~h}$, when a partial monolayer was formed, the supernatant was flicked off, washed the monolayer once with medium and $100 \mu \mathrm{l}$ of different test concentrations of test drugs were added on to the partial monolayer in microtitre plates. The plates were then incubated at $37^{\circ} \mathrm{C}$ for 3 days in $5 \% \mathrm{CO}_{2}$ atmosphere, and microscopic examination was carried out and observations were noted every $24 \mathrm{~h}$ interval. After $72 \mathrm{~h}$, the drug solutions in the wells were discarded and $50 \mu \mathrm{l}$ of MTT in PBS was added to each well. The plates were gently shaken and incubated for $3 \mathrm{~h}$ at $37^{\circ} \mathrm{C}$ in $5 \% \mathrm{CO}_{2}$ atmosphere. The supernatant was removed and $100 \mu \mathrm{l}$ of propanol was added and the plates were gently shaken to solubilize the formed formazan. The absorbance was measured using a microplate reader at a wavelength of 540 $\mathrm{nm}$. The percentage growth inhibition was calculated using the following formula and concentration of test drug needed to inhibit cell growth by $50 \%\left(\mathrm{IC}_{50}\right)$ values is generated from the dose-response curves for each cell line.

$\%$ Growth Inhibition $=100-\left(\frac{\text { Mean OD of individual test group }}{\text { Mean OD of control group }}\right) \times 100$

\section{RESULTS}

The preliminary phytochemical analysis inferred the presence of different classes of phytoconstituents which are depicted in Table 1.

\section{Characterization of Zn Nanoparticles}

The $\mathrm{Zn}$ nanoparticles synthesized were observed by change of colour to white precipitate, the precipitate was dried and used for UV spectrophotometer analysis Graph 1 shows the U.V spectrophotometer result with maximum absorption $270 \mathrm{~nm}$.

\section{SEM Analysis}

The Scanning Electron Microscope (SEM) analysis was used to determine the structure of the reaction products that were formed. SEM 
Table 1: Preliminary phytochemical analysis of aqueous extract of $A$. indicum

\begin{tabular}{ccc}
\hline SL NO. & TEST & INFERENCE \\
\hline $\mathbf{1}$ & Reducing Sugar & + \\
$\mathbf{2}$ & Tannin & + \\
$\mathbf{3}$ & Alkaloid & - \\
$\mathbf{4}$ & Saponin & + \\
$\mathbf{5}$ & Glycosides & + \\
$\mathbf{6}$ & Steroid & + \\
$\mathbf{7}$ & Flavanoids & + \\
$\mathbf{8}$ & Anthroquinones & + \\
$\mathbf{9}$ & Terpenoides & + \\
\hline
\end{tabular}

Table 2: MTT assay results showing cell viability (\%) based on concentration

\begin{tabular}{cccc}
\hline & \multirow{2}{*}{$\begin{array}{c}\text { Concentration } \\
\text { SL.No. }\end{array}$} & \multicolumn{2}{c}{ Cell Viability (\%) } \\
\cline { 3 - 4 }$(\mu \mathrm{g} / \mathrm{ml})$ & Sample & Standard(5-FU) \\
\hline $\mathbf{1}$ & 5 & 89.540 & 70.126 \\
$\mathbf{2}$ & 10 & 79.714 & 42.364 \\
$\mathbf{3}$ & 20 & 69.889 & 37.562 \\
$\mathbf{4}$ & 30 & 58.795 & 33.891 \\
$\mathbf{5}$ & 40 & 54.358 & 30.456 \\
$\mathbf{6}$ & 50 & 50.396 & 25.755 \\
Control & - & 100 & - \\
\hline
\end{tabular}

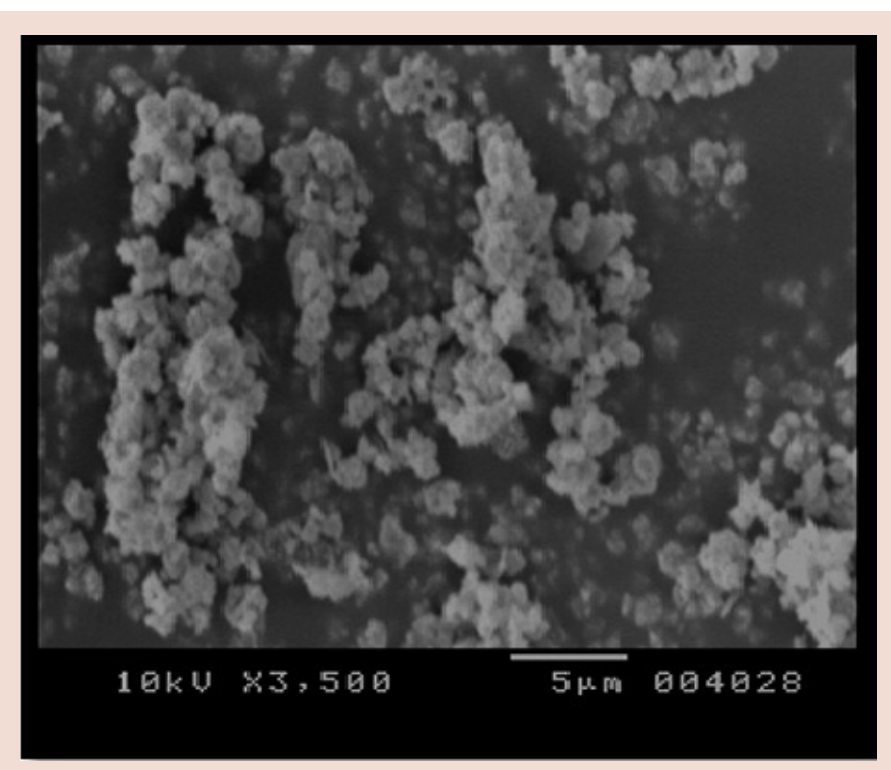

Figure-1 (a): SEM Image of Zn nanoparticles 3500X

image has showed scattered zinc particles as well as a number of aggregates. The SEM image showed broad range of relatively spherical shaped nanoparticles in the range of 50-500 $\mathrm{nm}$ in size (Figure 1a).

The nanoparticles with different concentration $(5-50 \mu \mathrm{g} / \mathrm{ml})$ were checked for their cytotoxicity against HeLa cell lines for cervical cancer using MTT assay (Table 2). The $\mathrm{IC}_{50}$ value was then calculated from the graph with \% Viability vs Drug Concentration which was found to be $45.82 \mu \mathrm{g} / \mathrm{ml}$. The effect was compared with control and standard (5-Fluorouracil). Results show dose dependent cytotoxicity at higher concentrations there is significant cell mortality (Graph 2).

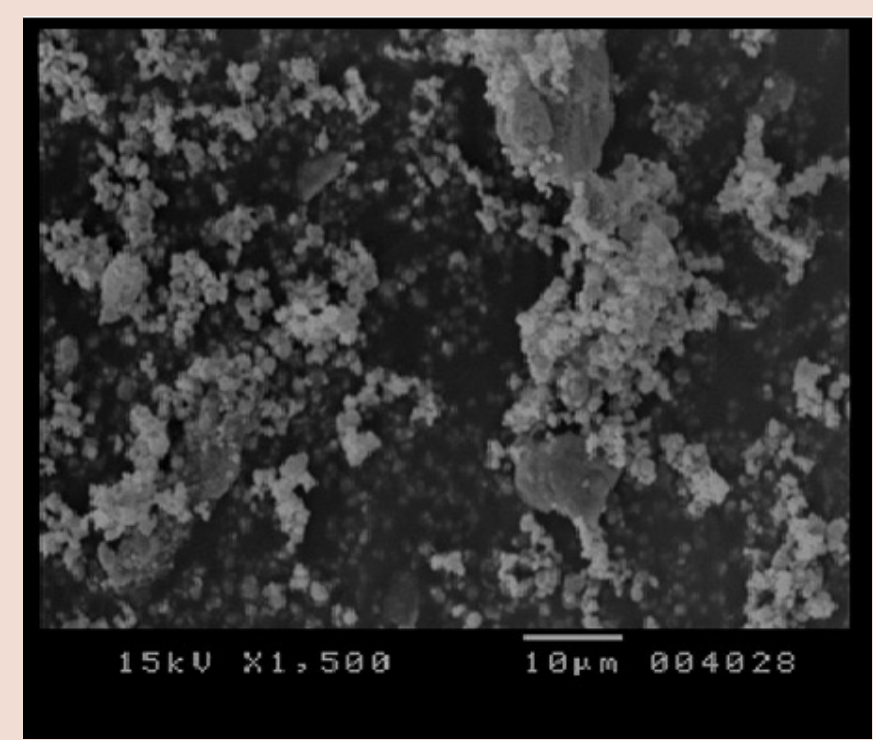

Figure-1 (b): SEM image of Zn Nanoparticles 1500X

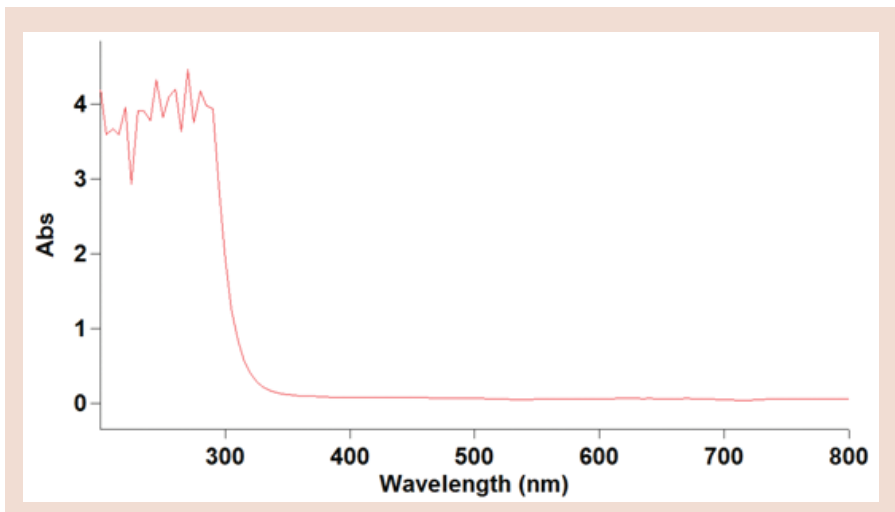

Graph 1: Absorption maximum of $\mathrm{Zn}$ nanoparticles

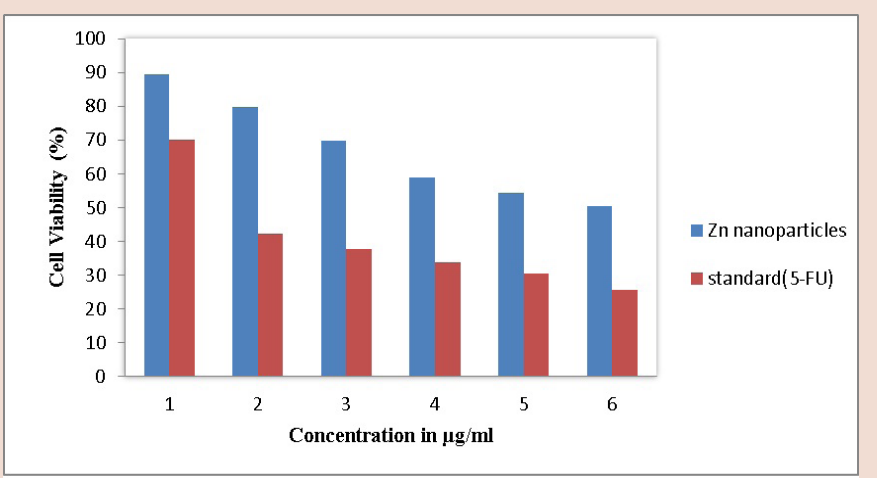

Graph 2: Graph showing the concentration of sample against the cell Viability

\section{DISCUSSION}

A. indicum is an important medicinal plant used traditionally to treat many human ailments. In the present study the preliminary phytochemical analysis of $A$. indicum revealed the presence of broad range 


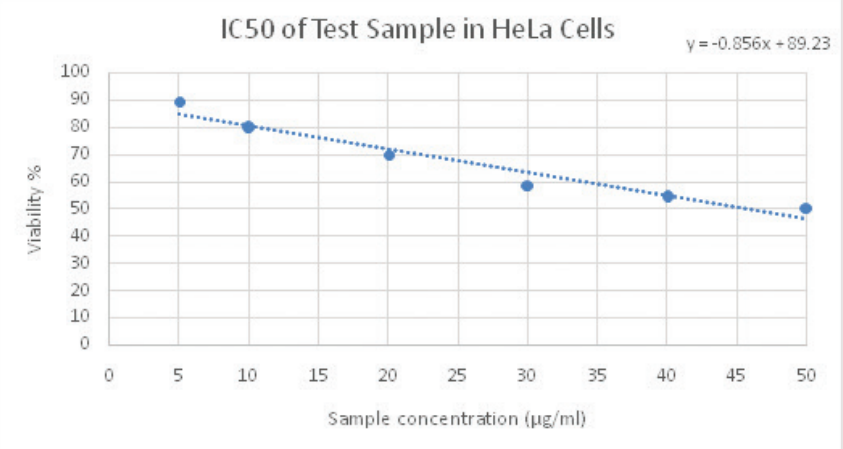

Graph 3: Graph showing IC $C_{50}$ Value of $\mathrm{Zn}$ nanoparticles against HeLa cell lines

of phytoconstituents like flavonoids, tannins, saponins, anthroquinones, terpenoides, glycosides and steroids (Table 1). These phytoconstituents are used as potent drugs in treating diabetes, cancer, inflammation and as potential antioxidants. ${ }^{22}$ The plant phytochemicals with anti-oxidant or reducing properties are usually responsible for reduction of metal compounds into their respective nanoparticles. The $\mathrm{Zn}$ nanoparticles were synthesized by using zinc acetate dihydrate as the precursor material with the plant extracts. These $\mathrm{Zn}$ nanoparticles when subjected to $\mathrm{UV}$-Vis characterization showed the maximum absorption at $270 \mathrm{~nm}$ (Graph 1). SEM analysis revealed that the nanoparticles were spherical in shape and found as aggregates in the range of 50-500 nm (Figure 1). When these $\mathrm{Zn}$ nanoparticles subjected to cytotoxicity assay exhibited potential cytotoxicity against HeLa cell lines with $\mathrm{IC}_{50}$ value of $45.82 \mu \mathrm{g} / \mathrm{ml}$ (Graph 3). The cytotoxicity was found to be in a dose dependent manner (Graph 2). These Zn nanoparticles may selectively kill the cancer cells by apoptosis induced by the production of reactive oxygen species (ROS) via p53 pathway. ${ }^{27}$ This ability of the $\mathrm{Zn}$ nanoparticles to inhibit the growth of cancer cell can be used in the treatment of cervical cancer.

\section{CONCLUSION}

The $\mathrm{Zn}$ nanoparticles synthesized using $A$. indicum, showed positive results for cytotoxic activity with an $\mathrm{IC}_{50}$ value of $45.82 \mu \mathrm{g} / \mathrm{ml}$. These positive results confirmed the cytotoxic potential of the $\mathrm{Zn}$ nanoparticles against cervical cancer. Thus $\mathrm{Zn}$ nanoparticles can be used as a potent drug in alternative therapy for treating the cervical cancer patients in the near future. Further potential of cytotoxicity against cancer can be enhanced by In vivo studies in animal models and human volunteers.

\section{ACKNOWLEDGMENT}

Authors are thankful to Department of Biotechnology, The Oxford College of Science, Bangalore for providing the necessary infrastructure for carrying out this work.

\section{CONFLICT OF INTEREST}

The author declare no conflict of interest.

\section{ABBREVIATION USED}

Zn: Zinc; HeLa: Henrietta Lacks; SEM: Scanning Electron Microscope; UV-Vis: Ultraviolet-Visible; MTT: 3-(4, 5-dimethylthiazol-2-yl)-2, 5-diphenyltetrazolium bromide; nm: Nanometer; Th1: TNF-a: Tumor Necrosis Factor; hrs: Hours; ml: Millilitre; M: Molar; gm: Gram; min: Minutes; KV: Kilovolts; DMEM: Dulbecco's Modified Eagle's Medium; EDTA: Ethylene Diamine Tetra Acetic acid; DMSO: Dimethyl Sulfoxide;
FBS: Fetal Bovine Serum; IU/ml: International Units/milliliter; $\mu \mathrm{g}: \mathrm{Mi}$ crogram; TPVG: Trypsin Phosphate Versene Glucose; cm: centimeter; mg: milligram; $\mu$ l: microliter; OD: optical density; 5-FU: 5-Fluro Uracil; IC: Inhibitory Concentration.

\section{REFERENCES}

1. Jae YS, Beom SK. Rapid biological synthesis of silver nanoparticles using plant leaf extracts. Bioprocess Biosyst Eng. 2008;32(1):79-84.

2. Cheon J, Horace G. Inorganic nanoparticles for biological sensing, imaging and therapeutics. J Mater Chem. 2009;19:6249-50.

3. Jitendra K, Meenakshi KC, Maheshwari M. Nanobiotechnology: Application of nanotechnology in diagnosis, drug discovery and drug development. Asian Journal of Pharmaceutical and Clinical Research. 2011;4(1):23-8.

4. Sharmila RD, Gayathri R. Green Synthesis of Zinc Oxide Nanoparticles by using Hibiscus rosa-sinensis. International Journal of Current Engineering and Technology. 2014;4(4): 2444-46

5. Kavitha KS, Syed B, Rakshith D, Kavitha HU, Yash wantha Rao HC, Harini BP. et al. Plants as Green Source towards Synthesis of Nanoparticles. International Research Journal of Biological Sciences. 2013;2(6):66-76.

6. Baker S, Satish S. Endophytes: Toward a Vision in Synthesis of Nanoparticles for Future Therapeutic Agents. Int J Bio-Inorg Hybd Nanomat. 2012;1:1-11.

7. Hanley C, Layne J, Punnoose A, Reddy KM, Coombs I, Coombs A, et al. Preferential killing of cancer cells and activated human $T$ cells using zinc oxide nanoparticles. Nanotechnology. 2008;19(29):295103-13.

8. Hanley C, Thurber A, Hanna C, Punnoose A, Zhang J, Wingett DG . The influences of cell and $\mathrm{Zn}$ nanoparticle size and immune cell cytotoxicity and cytokine induction. Nanoscale Res Lett. 2009;4(12):1409-20.

9. Nagao M. Physiosorption of water on zinc oxide surface. J Phys Chem. 1971; 75(25):3822-28

10. Horie M, Nishio K, Fujita K, Endoh S, Miyauchi A, Saito Y et al. Protein adsorption of ultrafine metal oxide and its influence on cytotoxicity toward cultured cells. Chem Res Toxicol. 2009;22(3):543-53.

11. Grabarek Z, Gergely J. Zero-length crosslinking procedure with the use of active esters. Anal Biochem. 1990;185(1):131-5.

12. Nair S, Sasidharan A, Divya Rani VV, Menon D, Nair S, Manzoor K, et al. Role of size scale of Zn nanoparticles and microparticles on toxicity toward bacteria and osteoblast cancer cells. J Mater Sci Mater Med. 2009;20(1):235-41.

13. John WR, Ezequiel M, Panagiota L, Denise G, Wingett. Zinc Oxide Nanoparticles for Selective Destruction of Tumor Cells and Potential for Drug Delivery Applications. Expert Opin Drug Deliv. 2010;7(9):1063-77.

14. Qu F, Morais PC. Energy levels in metal oxide semiconductor quantum dots in water-based colloids. J of Chem Physics. 1999;111(18):8588-94.

15. Qu F, Morais PC. The pH dependence of the surface charge density in oxidebased semiconductor nanoparticles immersed in aqueous solution. IEEE Transactions on Magnetics. 2001;37(4):2654-6.

16. Abercrombie M, Ambrose EJ. The surface properties of cancer cells: a review. Cancer Res.1962;22(5):525-48.

17. Degen A, Kosec M. Effect of $\mathrm{pH}$ and impurities on the surface charge of zinc oxide in aqueous solution. J Europena Ceramic Society. 2000;20:667-73.

18. Papo N, Shahar M, Eisenbach L, Shai Y. A novel lytic peptide composed of DLamino acids selectively kills cancer cells in culture and in mice. J Biol Chem. 2003;278(23):21018-23

19. Lappin MB, Campbell JD. The Th1-Th2 classification of cellular immune responses: concepts, current thinking and applications in haematological malignancy. Blood Rev. 2000;14(4):228-39.

20. Sayes CM, Reed KL, Warheit DB. Assessing toxicity of fine and nanoparticles: comparing in vitro measurements to in vivo pulmonary toxicity profiles. Toxicol Sci. 2007;97(1):163-80.

21. Croft M. The role of TNF superfamily members in T-cell function and diseases. Nat Rev Immunol. 2009; 9(4):271-85.

22. Archna S, Sharma RA, Hemlata S, Saharia RL. Phytochemical and Pharmacological Profile of Abutilon indicum L. Sweet: A Review. Int J Pharm Sci Rev Res. 2013;20(1):120-7.

23. Mohite MS, Shelar PA, Raje VN, Babar SJ, Sapkal RK. Review on Pharmacological Properties of Abutilon indicum. Asian J Pharm Res. 2012;2(4):156-60.

24. Harborne JB. In: Phytochemical methods, In: A guide to modern techniques of plant analysis. $3^{\text {rd }}$ ed. Chapman and Hall, London; 1998 P. 235.

25. Gnanasangeetha D, Sarala D. Thambavani. Biogenic Production of Zinc Oxide Nanoparticles Using Acalypha indica. An International Peer Review E-3 Journal of Sciences. 2014;4(1):238-46

26. Saraniya DJ, B. Valentin Bhimba. Anticancer Activity of Silver Nanoparticles Synthesized by the Seaweed Ulva lactuca In vitro. Open Access Scientific Reports. 2012;1(4):242

27. Akhtar MJ, Ahamed M, Kumar S, Khan MM, Ahmad J, Alrokayan SA. Zinc oxide nanoparticles selectively induce apoptosis in human cancer cells through reactive oxygen species. Int J Nanomedicine. 2012;7:845-57. 
PICTORIAL ABSTRACT

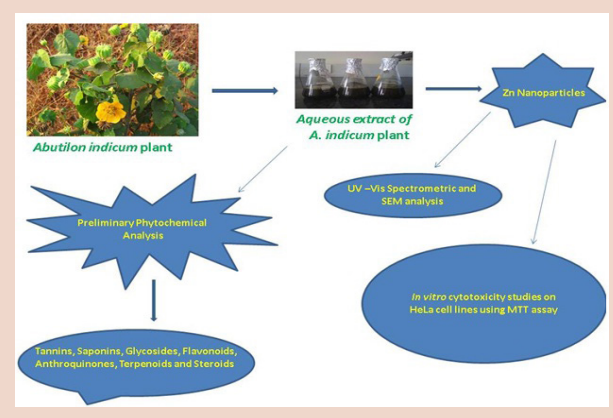

\section{SUMMARY}

- Abutilon indicum is a potent medicinal plant used in traditional medicine.

- The preliminary phytochemical analysis revealed the presence of broad spectrum of secondary metabolites.

- Zn nanoparticles synthesized from the aqueous extract of $A$. indicum showed strong cytotoxic activity against HeLa cell lines.

\section{ABOUT AUTHORS}

Dr. Vedamurthy A.B: Obtained his M.Sc., M.B.Tech., Ph.D degree from Gulbarga University, Gulbarga in 1999. He started his career as a Guest lecturer in Gulbarga University, Gulbarga in 1996. Thereafter he joined The Oxford College of Science as lecturer in 2000. During his tenure in The Oxford College of Science till October 2013 he has served in several important positions namely Reader, Professor \& Head of Biotechnology Department and Principal. He has created a productive learning environment that is student-centered. He joined Department of Biotechnology and Microbiology, Karnatak University, Dharwad in November 2013. His specialization includes Genetic Engineering, Molecular Biology, Plant Biotechnology, Agricultural Biotechnology, Medicinal and Aromatic plants, Bioactive compounds, Microbial \& Plant Pathology/Mycology.

Mr. Badarinath D: Kulkarni is a doctoral student at Karnatak University, Dharwad. He has done his masters from Bangalore University and worked as Asst. professor at The Oxford College of Science, Bangalore for four years. His research area includes Plant Biotechnology, Natural products, Phytochemistry. 